\title{
Food studies: Adding nuance to the sustainable food systems dialogue
}

\author{
Review by Keith Williams * \\ College of the North Atlantic, Carbonear Campus
}

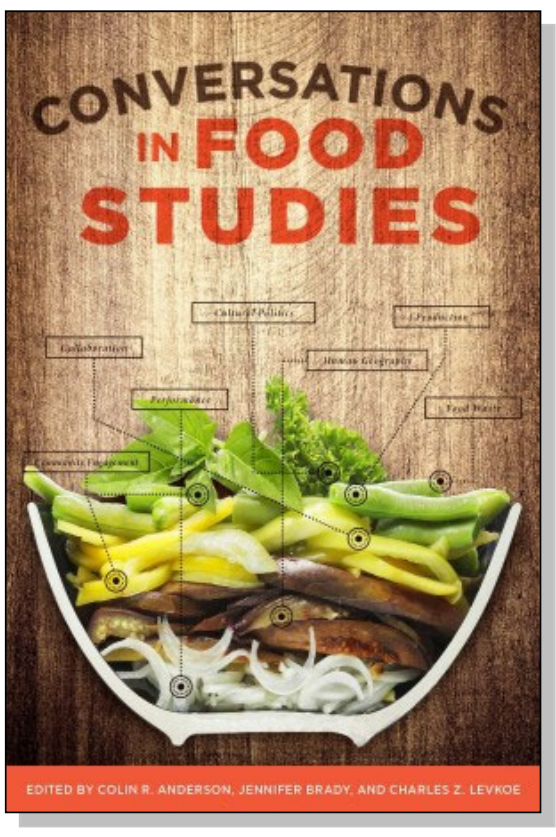

Review of Conversations in Food Studies, edited by Colin R. Anderson, Jennifer Brady, and Charles Z. Levkoe, (2016). Published by University of Manitoba Press, Winnipeg. Available as paperback and ebook; 312 pages. Publisher's website: https://uofmpress.ca/books/detail/conversations-in-food-studies

Submitted February 21, 2017 / Published online May 17, 2017

Citation: Williams, K. (2017). Food studies: Adding nuance to the sustainable food systems dialogue [Book review]. Journal of Agriculture, Food Systems, and Community Development, 7(3), 211-214. http://dx.doi.org/10.5304/jafscd.2017.073.002

Copyright (C) 2017 by New Leaf Associates, Inc.

$\mathrm{M}$ y motivation to review Conversations in Food Studies grew from a desire to understand how we can approach complex problemschanging attitudes and beliefs about diet, incorporating social and environmental values into

\section{* Keith Williams, Campus Director, College of the North Atlantic, Carbonear Campus; 4 Pike's Lane, Carbonear; Newfoundland and Labrador A1Y 1A7 Canada; keith.williams@.cna.nl.ca or peziza@hotmail.com}

Keith Williams is the Campus Director at College of the North Atlantic's Carbonear Campus. He is an educator and applied researcher with an interest in promoting food sovereignty for Canada's Atlantic Provinces. agricultural production, and addressing structural inequalities - to reduce poverty and food insecurity.

My work with various communities both in Canada and abroad has yielded this insight: the technical barriers to achieving a just and sustainable food system (such as growing food all year in northern climates and increasing crop yields) are more easily overcome than the socio-cultural and behavioral barriers. What is critical for food system transformation is an understanding of the human component; this is the task of food studies scholars. This defining volume tackles socio-cultural obstacles to a just and sustainable food system 
through work reported in a cross-sectional snapshot of predominantly Canadian scholarship, in the interdisciplinary field of food studies.

In this volume's foreword and introduction, Koç and Levkoe, Brady, and Anderson, respectively, advocate for a deep interdisciplinarity in food studies, including exploring interepistemic approaches to food that incorporate the knowledge systems of "farmers and fishers, Indigenous peoples and scientists" (Levkoe et al., p. 4). The editors are aware, however, that "the overall scope of the interdisciplinary work in the book is relatively narrow" and that "there is much work to be done to engage with and to draw in other perspectives to develop a more interdisciplinary and transdisciplinary field of food studies" (Levkoe et al., p. 13).

The section "Re-Presenting Disciplinary Praxis" examines participatory visual approaches to food system representation as a polyvocal challenge to established power relationships. One case discussed in a chapter in this section profiles a university student who makes a sculpture to represent her personal "food ecology" due to her aversion to what she perceives as the finality of text (Cadieux, Levkoe, Mount, \& Szanto). This case provides grounds for deprivileging text, a practice that could improve participation by those for whom academic research is not accessible. Another chapter explores performance as a participatory lens through which to view food system elements: “...'performer' and 'spectator' are made more mindful of the ecology around them" (Szanto, Wong, \& Brady, p. 61). The authors' fresh and provocative approach introduces tantalizing ways that performance could advance our understandings of knowledge, power, and perspective in food systems. The first two chapters resonate with the work of Al Etmanski, a Canadian community developer who identifies patterns to scale social innovations; for example, create an appropriate "container for your content" (Etmanski, 2015, p. 61), suggesting that the appropriate "container" can breathe "life into issues that affect us all" (Etmanski, 2015, p. 73). The embodied, and participatory, nature of visual and performative approaches enliven our understandings of the food system in a way that academic writing cannot.
The section entitled "Food System Governance" opens with a chapter on governance lessons from both agriculture and fisheries (by Lovitt, Mount, Khan, \& Clement), which is a strength, since most food system-related studies focus on either fisheries or agriculture, reflecting society's reductive approach to understanding and managing the food system. Elizabeth Beaton (2009) writes that rural Nova Scotians engage in a pluriactivity of livelihoods, including fishing, smallscale agriculture, forestry, and more; I see similar pluriactivity in rural Newfoundland. Equitable and authentic food system interventions can only happen when multiple relationships, among and within stakeholder groups, are considered-which requires a level of integration that is challenging from a governance perspective as fisheries and agriculture are normally found in different provincial and federal portfolios. Lovitt et al. recommend focusing on social and ecological goals for governance rather than simply assuming that "smallscale" equals "environmentally friendly" and just. The authors profile Off the Hook, a small directmarketing initiative between rural fishers from Digby County and urban consumers in Halifax, Nova Scotia's capital, using a community supported agriculture (CSA) model. The fishers receive a premium price for their fish in Halifax, which helps them to remain economically viable. A model based on premium prices catering to an urban elite could drive the business to supply fish exclusively to that market, excluding lower-income consumers who lack the disposable income to pay for premium-priced seafood. In addition to meeting the demands of their urban market, Off the Hook sells fish dockside in Digby, but it is unclear if their model includes provisions for lower-income consumers to access affordable local fish. Although Lovitt et al. contribute to the conversation on what constitutes a just and sustainable community supported fisheries (CSF) model, it would also be valuable to learn about models that include access for lower-income consumers-if such models exist.

"Un-doing Food Studies: A case for flexible fencing" does not challenge the nascent discipline of food studies, as the title suggests, but challenges assumptions underlying the alternative food system movement. Sprague and Kennedy examine how 
the cultural politics of various alternative food networks (AFNs) maintain inequitable power relationships. Many of the AFNs studied rely on social transformation via the attitude, behavior, change $(\mathrm{ABC})$ model, i.e., "if people were aware of where their food came from and experienced the taste of locally grown food, they would buy, grow, and eat more local food" (p. 208). Most AFN approaches to food system change place consumers as the change agents. While empowering in one sense, foisting the responsibility for food system change predominantly on consumers serves to reinforce the neoliberal status quo with its entrenched inequities. Nonetheless, Sprague and Kennedy criticize the $A B C$ lexicon as insufficiently nuanced to effect significant social transformation. The authors of this chapter shed light on the structural inequities in some common AFN activities; their call to create more inclusive and equitable alternatives to existing AFN activities is long overdue.

"Scaling Learning in Agri-food Systems" comprises the book's final two chapters. Braun and Bogdan profile two Albertan cases: producers transitioning to sustainable farming, and rural women increasing their household, and community, food security. Braun and Bogdan suggest that reflection on routine practices, such as cooking and shopping, leads to incremental perspective transformations and consequently to behavior change. More than individual agency or externally imposed legislation, social practice theory maintains that behavioral change is fostered through the "development and enactment of practices themselves" (p. 304). Their use of social practice theory helps to unravel the "practice" element of transformative learning in the two cases presented. Social practice theory is an intriguing framework to approach one of the most intractable barriers to food system transformation: behavior change.

Sumner's (2015, and Sumner \& Wever in this book) critical food pedagogy supports alternatives to the current dysfunctional food system; examines explicit and implicit food system power relationships; and takes an emancipatory and anticolonial stance. In their chapter, Sumner and Weaver identify school gardens as significant sites of food learning and strongly advocate for allocated government funding. Two years ago I led a program evaluation of the community gardens in Brandon, Manitoba (Williams \& Leadbeater, 2015). Our key findings were that $98 \%$ of respondents viewed community gardens as "places of learning" and approximately $60 \%$ felt that their community connections increased because of community gardening. Funding for the community gardens was based on "soft money" and relied heavily on volunteer support (Williams \& Leadbeater, 2015). Community gardens, like school gardens, have significant social impact and should also be considered for allocated government funding. The authors cite Guthman's (2011) exhortation that "those who want to teach people how to make better food choices should spend more time reforming the policies that allow bad food in the first place" (p. 337) and offer us an expanded concept of critical food pedagogy that includes advocacy and direct action.

Very few of the chapters in this volume deal explicitly with rural communities, and none discusses food in First Nations communities. The focus of study was predominantly urban, and from Canada's central and western provinces. A national-level study by Tarasuk, Mitchell, and Dachner (2016) revealed that $12.0 \%$ of Canadian households experienced food insecurity in 2014. In that same year, and of the provinces and territories surveyed (all but the Yukon, Ontario, and Newfoundland and Labrador), Nunavut had the highest level of food-insecure households (46.5\%) Northwest Territories had the second highest at 24.1\%, and Nova Scotia and New Brunswick ranked third and fourth with household food insecurity levels of $15.6 \%$ and $15.2 \%$, respectively (Tarasuk et al., 2016). It is imperative to have a sense of the food studies landscape in northern and Indigenous communities and in the Atlantic Provinces, given the high rates of household food insecurity in those areas.

This lively collection of diverse food studies papers delivers on its promise of boundary-testing interdisciplinarity. The insights presented within its pages reflect an intellectually sophisticated dialogue on food studies in Canada, providing hope for equally sophisticated food system interventions. My training in the agricultural sciences, rooted in a positivist and implicitly neoliberal worldview, 
offers up a simple solution to food insecurity: grow more food more efficiently, and distribute it more effectively. However, after reading this book I see that a truly transformative approach to food systems change will require researchers to "get their hands dirty" with other stakeholders — such as farmers, fishers, Indigenous people, and more-in ways that are broadly accessible, respect different knowledge systems, and challenge status quo power relations.

\section{References}

Beaton, E. (Ed.). (2009). Connecting the dots: Social and scientific perspectives on agriculture and rural life in Atlantic Canada. Sydney, Nova Scotia: Cape Breton University Press.

Etmanski, A. (2015). Impact: Six patterns to spread your social innovation. Ashland, Massachusetts: Orwell Cove Press.
Guthman, J. (2011). Weighing in: Obesity, food justice, and the limits of capitalism. Los Angeles: University of California Press.

Sumner, J. (2015). Learning to eat with attitude: Critical food pedagogies. In R. Flowers \& E. Swan (Eds.), Food pedagogies (pp. 201-214). Burlington, Vermont: Ashgate Publishing.

Tarasuk, V., Mitchell, A., \& Dachner, N. (2016). Household food insecurity in Canada, 2014. Toronto: Research to Identify Policy Options to Reduce Food Insecurity (PROOF). Retrieved from http://proof.utoronto.ca/resources/proof-annualreports/annual-report-2014/

Williams, K. \& Leadbeater, N. (2015). Evaluation of Healthy Brandon's Food Action Investments (Report submitted to Healthy Brandon steering committee). Brandon, Manitoba. 